\title{
The Role of Strategic Technology Alliances (STA) Towards Organizational Performance in Manufacturing Industry: The Perspective of Developing Countries
}

\author{
Juhaini Jabar ${ }^{1}$, Claudine Soosay ${ }^{2}$, Fararishah Abdul Khalid1, Haslinda Musa ${ }^{1} \&$ Norfaridatul Akmaliah Othman ${ }^{1}$ \\ ${ }^{1}$ Faculty of Technology Management \& Technopreneurship, Universiti Teknikal Malaysia Melaka, Malaysia \\ ${ }^{2}$ Division of Business, School of Management, University of South Australia, Adelaide, Australia \\ Correspondence: Juhaini Jabar, Faculty of Technology Management \& Technopreneurship, Universiti Teknikal \\ Malaysia Melaka, Malaysia. E-mail: juhaini@utem.edu.my
}

Received: January 7, 2015 Accepted: April 24, 2015 Online Published: June 13, 2015

doi:10.5539/ass.v11n16p38 URL: http://dx.doi.org/10.5539/ass.v11n16p38

\begin{abstract}
Purpose: This research investigates strategic technology alliances (STA) in Malaysian manufacturing firms and the impact on organizational performance. The outcomes of this paper shed light on the underpinning theories under Resource Based View (RBV) and Organizational Learning (OL) as an antecedent for the successful implementation of strategic technology alliances in the manufacturing industry. At the end of the paper provides a model that describing the success factor of strategic technology alliances en route to improve organizational performance and remain competitive.
\end{abstract}

Design/methodology/Approach: Research conducted through survey design by collecting questionnaires from 335 Malaysian manufacturers. The empirical analysis performed by using structural equation modeling (SEM) to represent the findings as this statistical method is more robust compared to others.

Findings: The empirical analysis show that absorptive capacity, type of alliance and strategic technology alliance has positive relationship towards improving organizational performance in terms of market share, profit, sales level and manufacturing capabilities. However, in the other coin, resource base availability is insignificant towards organizational performance. Furthermore, technology transfer also only partially mediates STA and organizational performance. Despite the onset of successful alliance formation and resultant technology transfer, firms still need to invest in developing their resources, employee skills, production methods and industrial processes in order to sustain their competitiveness in the global economy.

Originality/value: Many organization embrace technology transfer as part of the strategic weapons to maintain business sustainability. However, there is lack of empirical evidence profiling the antecedent on how organization could success in becoming the developers of their own technology. Therefore, this research attempts to provide a model as guidance to managers in developing country as a key to success in forming technology alliances with foreign countries.

Keywords: strategic technology alliances, resource base view and organizational learning

\section{Introduction}

Technology is recognized as one of the most important factors for remaining competitive in the global business environment. The successful industrialization of many Asian economies (such as Korea and Taiwan) is attributed to their ability to exploit technological competencies. These countries have evolved from initially acquiring foreign technology to subsequently becoming developers of their own technology. The challenges of globalization and rapid technology change are especially faced by manufacturing organizations in developing countries, who are constantly pressured to examine their production strategies and capabilities (Hitt, 1998; Ireland \& Hitt, 1999). As such, alliances are being considered increasingly as a measure for such firms in acquiring external technologies with reduced time, costs, and risks involved (Lei, 1993; Das \& Teng, 1998).

More recently, the term 'strategic technology alliances' (STAs) (Colombo, Grilli, \& Piva, 2006) has received much attention in the literature, where these types of partnerships involve research joint ventures, technology transfer, joint product development, technology sharing, and commercial agreements involving technology. The 
growing stream of literature on STAs (Hagedoorn \& Sedaitis, 1998; Ju et al., 2005) also highlights how organizations can develop technological competencies and acquire external knowledge. Manufacturing organizations rely on STAs to import technologies that can maintain and enhance their performance. These firms usually form alliances to access complementary resources (Chung, Singh, \& Lee, 2000; Hitt et al., 2000) and increase their competitiveness (Arya \& Lin, 2007). Additionally, organizations from developing countries also exercise STAs to import foreign technologies given the dearth of indigenous capabilities to develop their own technologies (Jegathesan, Gunasekaran, \& Muthaly, 1997; Jamali, 2004).

As a developing country, Malaysia currently strives to transform its manufacturing industry into being resilient, broad-based, and competitive internationally since its economic growth and gross domestic product (GDP) depend largely on this industry (Rashid et al., 2014; Rashid, Jabar, Yahya, \& Shami, 2015). As such, STAs can be viewed as a learning platform to enhance the performance of its manufacturing industry. This research examines the STA initiatives of Malaysian manufacturers that lead to technology transfer and improved organizational performance. It is acknowledged that there are currently limited studies in the area of STAs in Malaysia (see, for example, Arshad, 2002; Wahab, Abdullah, \& Rose, 2009). Past studies about Malaysia have focused on the impact of national culture on alliances (Bhaskaran \& Gligorovska, 2009), factors affecting international joint ventures (Lyles et al., 1999; Sulaiman, Kechik, \& Wafa, 1999), partner selection (Ghani \& Subhan, 2005), and industry-university collaborations (See et al., 2007). Stemming from the resource-based view, organizational learning, and studies on technology acquisition in other developing countries (Jegathesan, Gunasekaran, \& Muthaly, 1997; Di Benedetto, Calantone, \& Zhang, 2003; Erensal \& Albayrak, 2008; Tsai \& Wang, 2008; Tsai, 2009), this study explores the factors influencing STAs in Malaysia's manufacturing industry. Thus, this research provides an insight to the following questions as below:

a) Do the resources lacking within an organization give rise to the formation of STAs?

b) Does organizational learning affect the alliance formation?

c) Do STAs formed by manufacturing organizations enhance their performance?

d) Does technology transfer as a result of the alliance also impact organizational performance?

\section{The Role of Strategic Technology Alliances in Manufacturing Industry}

The term 'strategic alliance' is often used as a concept to describe a wide range of cooperative partnerships and joint ventures among firms in different countries (Lynch, 1989; Mockler, 2001). Such alliances are agreements between companies (or partners) to reach objectives of a common interest based on cooperation between these companies (Pellicelli, 2003). Strategic alliances are also defined as inter-firm collaborations that involve the use of resources and governance structure of independent firms to achieve a specific organization-related goal or a goal set up by both firms (Parkhe, 1993). They serve as a gateway to the distribution and appropriation of technological capability and knowledge that could be the source of a firm's competitive advantage (Mowery \& Rosenberg, 1989; Lee, 2007).

Various organizations, regardless of size, have benefitted by acquiring technologies through STAs. Vanhaverbeke, Duysters and Noorderhaven (2002) argued that these external technologies enable organizations to stay abreast with less time, complexity, and cost of internal technology development. The technological capacity of firms is increased, leading to competitiveness in the industry (Montoya, Zarate, \& Martin, 2007). The increasing importance of organizations acquiring external technologies has instilled research into this area recently. The growing number of alliances formed across countries indicates organizations' significant efforts to enhance their technological capabilities (Hagedoorn \& Sedaitis, 1998; Norman, 2004). However, studies of alliances with high-technology organizations have predominantly been conducted in developed nations, mainly in the US (Hagedoorn, Carayannis, \& Alexander, 2001; Norman, 2004; Soh \& Roberts, 2005; Rothaermel \& Deeds, 2006; Ybarra \& Turk, 2009). Other studies on STAs have looked at Finland (Vilkamo \& Keil, 2003), Italy (Colombo, Grilli, \& Piva, 2006), Greece (Pateli, 2009), and Russia (Hagedoorn \& Sedaitis 1998). More recently, researchers have started to focus on Taiwan (Ju et al., 2005; Tsai \& Wang, 2009) and China (Chen \& Wang 2009). These studies highlight that developing countries generally lack resources and capabilities in R\&D to develop their own technologies (Lee \& Tan, 2006). This inadequacy compels firms to acquire and adopt external technologies through STAs to compete in global markets (Wahab, Abdullah, \& Rose, 2009). As such, the literature on STAs in developing countries warrants further empirical research (Wahab, Abdullah, \& Rose, 2009).

Malaysia, for example, has been relying on foreign direct investments (FDIs) as a source of technology inflow. In 2010, the total FDI inflow into Malaysia was USD7.0 billion compared with USD1.4 billion in 2009, indicating an impressive growth of 409.7 per cent (Ministry of International Trade and Industry 2010). This 
increase indicates that FDIs are still a major contributor to foreign technology in the nation (Malaysian Industrial Development Authority 2008). Additionally the Malaysian government has sanctioned the move towards forming alliances with more advanced nations in acquiring technology, especially in upgrading and enhancing its manufacturing industry (Economic Planning Unit 2006). Public sector institutions, such as the Malaysian Industrial Development Authority (MIDA) and the Ministry of Science, Technology and Innovation (MOSTI) were set up to facilitate collaborative relationships in ensuring successful transfer of knowledge, technology, and R\&D activities in the manufacturing industry (Malaysian Industrial Development Authority 2008; Ministry of Science Technology and Innovation 2010).

\section{Theoretical Context and Research Proposition}

\subsection{Resource Availability}

According to the resource-based view (Barney, 1991), firms constantly seek valuable, rare, inimitable, and non-substitutable (VRIN) resources that are the source of competitive advantage (Gulati, Nohria, \& Zaheer, 2000). 'Valuable' resources utilize opportunities and minimize uncertainties and risks in the firm's environment. A large number of firms do not own 'rare' resources because a resource possessed by various firms cannot be considered a source of competitive advantage. 'Inimitable' resources are difficult for other firms to copy, reproduce, or obtain. 'Non-substitutable' resources cannot have any strategically equivalent substitutes for them, as substitutable resources will not deliver a sustainable competitive advantage to the firm possessing them. Organizations form alliances to access these resources, such as newly developed technologies and processes (Nagarajan \& Mitchell, 1998), top managerial skills (McGee, Dowling, \& Megginson, 1995), and local market knowledge (Zhan et al., 2009).

Some resources are tacit in nature and can be transferrable through alliances (Green, Welsh, \& Dehler, 1996; Poon, 2005; Collins \& Hitt, 2006). For example, technological knowledge embedded in the organization can be complex and difficult to assimilate. This tacit form of knowledge is unique to the organization and not easily learnt by others. Small firms in a vulnerable strategic position usually see large firms as potential valuable partners for collaborations (Eisenhardt \& Schoonhoven, 1996). Traditionally, large firms are found to be at the forefront of new technologies and manufacturing processes (Colombo, 1995; Stuart, 2000; Santoro \& Chakrabarti, 2002). However, the organizations possessing higher technical skills and capabilities have lower tendencies to form equity alliances to protect their core competencies and mitigate risks involved in such collaborations (Dunne, Gopalakrishnan, \& Scillitoe, 2009). Specifically, firms that lack resources have a higher need for alliances compared with firms who are well endowed (Ahuja, 2000b). It is known that many organizations in Malaysia lack R\&D resources to develop and commercialize their own technologies and need to acquire such technologies, innovations, and capabilities externally (Wahab, Abdullah, \& Rose, 2009). Therefore, the research proposes that:

Hypothesis 1: The organization's existing resources are negatively related to STAs (where the less resources the organization has, the more likely they will form the alliance).

\subsection{Absorptive Capacity}

Organizational learning involves the utilization and distribution of information to personnel and the procedures by which this information is processed and incorporated in the firm. It also relates to the firm's R\&D activities and knowledge of their qualified workers. However, firms need to attain a certain level of learning ability which is related to the absorptive capacity or organization's knowledge overlap in order to reap the benefits from organizational learning (Zahra \& George, 2002), which in turn, enable firms to meet current technology and market needs. A firm's innovative competencies are associated with its capacity to identify and value new external information while incorporating and applying knowledge for the firm's commercial advantage. Hence, a firm's absorptive capacity is largely related to the firm's level of prior knowledge (Cohen \& Levinthal, 1990). Strategic technology alliances facilitate the learning and acquisition of new knowledge either through internal development of new products and services as a result of anexternal technology acquired (Cohen \& Levinthal, 1989; Schoenmakers \& Duysters, 2006). This situation highlights the importance of selecting suitable alliance partners to reap the benefits of organizational learning (Hitt et al., 2000). Learning in technology alliances involves the transfer of tacit knowledge and technological capabilities are best learnt through face to face learning (Mowery, Oxley, \& Silverman, 1996). Through alliances knowledge is acquired and embedded to suit the organizational culture, as well as to enhance the competencies of the workforce (Dogsdon, 1993). Based on these reasons, alliances are particularly popular with emerging markets.

The absorptive capacity and current level of knowledge are therefore important in ensuring successful learning outcomes through alliances (Perez-Nordtvedt, Babakus, \& Kedia, 2010). Absorptive capacity determines the 
organization's ability to discern the partner's R\&D expertise and technology (Fang \& Zou, 2010) that is vital for capability development and technology transfer. Transferring embedded knowledge between partners is a complex process where firms from both emerging and developed markets must be willing to share expertise and skills (Hitt et al., 2000). Tacit knowledge and capabilities are not easily transferrable in the alliance when one or both partners lack the absorptive capacity (Schweizer, 2005). Based on the discussion, transferring tacit knowledge is complicated; hence organizations need to ensure that the fundamental knowledge is ready to guarantee successful organizational learning will take place in order to effectively absorb the new capabilities through alliances. Therefore, it is hypothesized that:

Hypothesis 2: The organization's absorptive capacity is positively related to STA formation.

\subsection{Type of Alliance}

Studies by Anand and Khanna (2000) and Awazu (2006) indicated that successful learning in collaborations depends on the right type of alliances formed to ensure that the objectives of the partnership are met. For example, non-equity alliances, such as licensing, require minimal or no resource commitment. The commitment required in this type of collaboration is usually non-monetary, for example, the organization's effort (Kurukawa, 1997). However, equity alliances and joint ventures require the organization to invest a certain amount of resources as a sign of commitment towards the collaboration. Identifying and selecting the right type of alliance will ensure objectives of organizations are met as success in this area rests upon the ability to determine which alliance type will deliver the benefits sought. Firms also need to understand the strategic implications of choosing one type of alliance over another to reap the full benefits of technology alliances formed.

Various authors acknowledge greater learning opportunities in joint ventures and equity alliances compared with non-equity alliances (Shenkar \& Li, 1999; Anand \& Khanna, 2000; Simonin, 2004). For example, studies by Hastings (1999) and Peek, Rosengren and Kasirye (1999) found that international joint ventures do not always lead to increased firm performance. However, this type of collaboration can create new knowledge and competencies that will eventually lead to innovation and competitive advantage (Bakerma et al., 1997; Tsang, 2002). In terms of developing new products in the pharmaceutical industry, equity alliances are a popular choice for early phase of product development (Bierly III, 2004). In relation to this, Anand and Khanna (2000) found strong evidence of value creation through learning in joint ventures compared with licensing agreements, with joint ventures being more complex and dealing with higher ambiguity. Additionally, Anand and Khanna (2000) also indicated that the impacts of learning are stronger in R\&D joint ventures compared with other joint ventures. There is also a high tendency of collaborations between firms possessing high familiarity and experience with each other through previous collaborations (Kim, 2009). This familiarity will minimize the risk of opportunism.

Forming equity based alliances is the most effective way to assist knowledge transfer between partnering firms (Shenkar \& $\mathrm{Li}, 1999$ ), as this type of alliance encourages regular interactions and greater commitment of resources in the collaboration (Uzzi, 1997). Firms have found that equity alliances increase their patent rates significantly (Mowery, Oxley, \& Silverman, 1996). The structure of alliances ranges according to the complexity of the partnership agreement and risks involved highlighting type of alliance plays a crucial part in determining the success of the collaboration. Some alliances face high risk; that is, international alliances have greater termination and failure rates (Sadowski \& Duysters, 2008). Successful learning outcomes depend on the type of alliances coupled with the opportunities they bring (Dussauge, Garrette, \& Mitchell, 2000). From the discussion, the choice of the type of alliance can enhance or impair learning objectives. Therefore, it is argued that the firms will achieve their goals through the right type of alliance involving low risks, high commitment, and learning opportunities. This leads to the following hypothesis:

Hypothesis 3: The adoption of a more formal alliance (specifically joint ventures and equity alliances) by an organization is positively related to STA formation.

\subsection{The Outcomes: Organizational Performance}

There are various performance measures described in the literature to assess the outcomes of alliances. This is because research on alliance performance is complex, as collaborations are based on multifaceted objectives (Evans, 2001). Past studies have indicated that firms forming alliances have achieved superior performance in new product development (Lee, 2007); asset and investment returns (Goerzen, 2007); learning and efficiency levels (Nielsen, 2007); partner satisfaction (Judge \& Dooley, 2006); product, market, and financial performance (Jones, Lanctot, \& Teegen, 2000); profitability (Hagedoorn \& Schakenraad, 1994); and innovation (Ahuja, 2000a).

Organizations possessing advanced technologies, knowledge, and competencies will perform significantly better and have higher innovative abilities compared with firms that lag in technology (McEvily, Eisenhardt, \& Prescott, 
2004). Since external technology acquisition enables firms to stay abreast with technology developments with less time and costs incurred (Vanhaverbeke, Duysters, \& Noorderhaven, 2002), firms are able to develop their technological capabilities and sustain performance in dynamic markets (Henderson \& Cockburn, 1996; Montoya, Zarate, \& Martin, 2007). Therefore, it is argued that technology alliances are becoming a popular innovation strategy for both large and small organizations to enhance their competitiveness. Accordingly, the following hypothesis is predicted:

Hypothesis 4: STAs formed by organizations lead to enhanced organizational performance.

\subsection{Mediating Effect: Technology Transfer}

Solo (1972) first defined technology transfer as a process of transporting technology from one organization to another, or even across organizations in different countries. This transfer may involve products, processes, or even personnel. Technology transfer is an extensive, multifaceted, and dynamic process, which, when successful, is based on various factors (Kumar, Kumar, \& Persaud, 1999; Walter, 2000) and occurred as a result of alliances formed between firms. It offers organizations new systems, technologies, and products, as well as improved technological processes (Hoffman \& Girvan, 1990; Guan et al., 2006).

It has been established that firms that benefit from technology transfer are more innovative (Spivey et al., 1997; Un, Cuervo-Cazurra, \& Asakawa, 2010) and successful in terms of firm performance (McEvily, Eisenhardt, \& Prescott, 2004), economic expansion, and industrial advancement (González-Alvarez \& Nieto-Antolín, 2005). Based on the existing literature, it can be conceived that since STAs enable technology transfer between partners; and since the newly introduced systems, technologies, and processes can enhance overall firm performance, we argue that technology transfer is a mediating factor. Therefore, this study hypothesizes that:

Hypothesis 5: Technology transfer significantly mediates the relationship between STA and organizational performance.

Figure 1 shows the relationship between the antecedents of Strategic technology Alliances (STA), technology transfer and organizational performance.

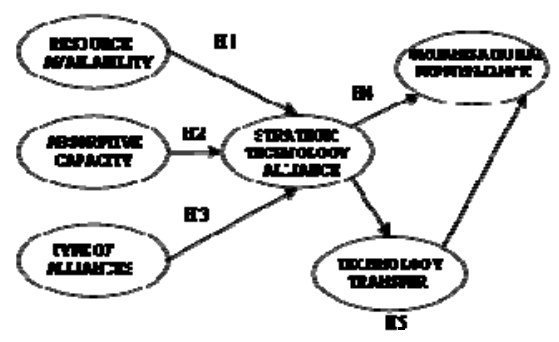

Figure 1. Conceptual framework

\section{Methodology}

\subsection{Data Collection}

Prior to data collection, a survey instrument validated through two different stages. The initial stage is much related on selecting the appropriate factors that is relevant to the scope of study by tracing literature under technology transfer. Meanwhile, in the second stage of questionnaire development, involved face to face validation with the managers from the selected organizations. After completed validation process, the questionnaires were ready to distribute through random sampling using generator software. Thus, in order to answer the research hypothesis, participants of this research were selected from the 2008 Federation of Malaysian Manufacturers directory. A random sample of 2,500 organizations that has been in operation with a minimum of three years was contacted through mails and emails inviting them to participate. This research adopted multiple source approach as the key respondents for this study ranging from varies level which is competent to answer the questionnaire as such; $\mathrm{CEO} / \mathrm{MD}$, senior engineers, and production and operations managers from manufacturing organizations involved in technology alliances. The process yielded 569 executives agreeing to participate, and emails were subsequently sent to complete an online survey with assigned passwords and restricted access. Till the end, 343 completed surveys received and yielding a 13.72 per cent response rate. Out of these, 335 (13.40 per cent) surveys were found usable for this study. 


\subsection{Variables and Measures}

The questionnaire consists of three sections. The initial section is focusing on the descriptive data as such company name, number of employees, designation, type of business and strategic technology alliance. The measurement underlines STAs include joint ventures, equity alliances, and non-equity alliances, and respondents were asked to indicate the number of alliances formed in the past three years of operation in order to gauge the commitment, investment, and risks involved. These items are adopted from Antoncic et al. (2007). Items for this construct are based on the number alliances formed by the organisation within three years where, $1=10$ or fewer, $2=11$ to $15,3=16$ to 20 , and $4=$ more than 20 . The second section relies on the measurement of resource base view, absorptive capacity and type of alliances.

Resource availability is measured using seven items adopted from Dunne, Gopalakrishnan and Scillitoe (2009) and modified to suit the context of this research. Items involved respondents' judgment of their organization's number of patents, cash flow condition, commercialization activities, number of previous alliances formed, and manufacturing ability. Absorptive capacity used six items to assess the organization's absorptive capacity, based on Cohen and Levinthal (1990). Respondents were required to rate their organization's ability in terms of experience, level of expertise, amount of money invested in training, and R\&D. Five items are used to measure the risk associated with the type of alliances. Three items required respondents to rate the type of alliances (joint venture, equity alliance, or non-equity alliance) that will result in the strongest learning outcomes based on the studies by Anand and Khanna (2000) and Simonin (2004). Other items rated the learning outcomes based on the type of alliance formed. All items for the independent variables were measured on a 7-point Likert scale ranging from 1 = strongly disagree to $7=$ strongly agree.

Meanwhile, in the last section much related about the measurement of technology transfer and organization performance. Organizational performance is measured using four items adopted from Geringer and Hebert (1991). Notably, this study evaluates the performance of STAs based on managers' perceptions. Managers were required to rate their organizational performance based on market share, profit, sales level, and manufacturing capabilities as a result of the STAs formed. Items for this constructs are based on a 7-point Likert scale ranging from $1=$ strongly disagree to $7=$ strongly agree in the survey. Three items measuring technology transfer were adopted from existing literature (see, for example, Mohamed, 1995; Doz, Olk, \& Ring, 2000; Kotabe, Martin, \& Domoto, 2003). These items required respondents to rate the benefits that they have experienced through technology transferred from their partners. These items are based on a 7-point Likert scale where $1=$ strongly disagree and $7=$ strongly agree. The details of the measurement used in this research can be trace in the appendix 1.

\section{Empirical Result}

\subsection{Descriptive Analysis}

Table 1. Descriptive statistics of the respondent

\begin{tabular}{llllllll}
\hline \multirow{2}{*}{ Sectors } & Respondents & Population & & & \\
& Frequency & $\mathbf{\%}$ & Frequency & $\mathbf{\%}$ & SMEs & large & Total \\
\hline Basic Metal Product & 24 & 7.2 & 175 & 7.0 & 18 & 6 & 24 \\
Electrical and Electronics products & 109 & 32.5 & 850 & 34.0 & 58 & 51 & 109 \\
Engineering Supporting & 176 & 52.5 & 1380 & 55.2 & 97 & 79 & 176 \\
Others $^{\#}$ & 26 & 7.8 & 95 & 3.8 & 15 & 11 & 26 \\
Total & $\mathbf{3 3 5}$ & $\mathbf{1 0 0}$ & $\mathbf{2 5 0 0}$ & $\mathbf{1 0 0}$ & $\mathbf{1 8 8}$ & $\mathbf{1 4 7}$ & $\mathbf{3 3 5}$ \\
\hline
\end{tabular}

\# represents firms from food, automotive, oil and gas, aerospace, medical, and defense sectors.

Table 1 profile the respondent characteristic in forms of frequency and percentage data. Most of the respondent derived from basic metal product ( 24 respondent), electric and electronic products (109 respondent), engineering supporting (176 respondents) and others industries ( 26 respondents). Then, firm were divided into two categories: a small and medium enterprise (SMEs), which is consist of firm with less than 150 employees, while large organizations with more than 150 employees (Department of Statistics Malaysia 2009). Therefore, from the table 1, there were 188 SMEs and 147 large organizations in the sample that are involved in this research. 


\subsection{Reliability and Validity of Constructs}

Based on the recommendation from Garver and Mentzer (1999), measurement of the reliability for all constructs was performing using Cronbach's $\alpha$, composite reliability, and average variance extracted (AVE). Table 2 shows that all the constructs had Cronbach's alpha and composite reliability values of above .70 and .60 , respectively. In addition, the AVE values for these constructs were all above the recommended threshold value of .50. Therefore, all the scales were considered to exhibit sufficient internal reliability and consistency (Nunnally, 1978; Bagozzi \& Yi, 1991).

Table 2. Reliability analysis

\begin{tabular}{lllll}
\hline Constructs & $\begin{array}{l}\text { Cronbach's } \\
\text { alpha }\end{array}$ & $\begin{array}{l}\text { Composite } \\
\text { reliability }\end{array}$ & $\begin{array}{l}\text { Average } \\
\text { (AVE) }\end{array}$ & variance extracted \\
\hline $\begin{array}{l}\text { Technology transfer (TT) } \\
\text { Strategic technology alliance }\end{array}$ & .85 & .74 & .60 \\
(STA) & .86 & .85 & .67 & \\
Organizational performance & .82 & .75 & .60 & \\
(OP) & .87 & .86 & .62 & \\
Type of alliance (TA) & .87 & .91 & .62 & \\
Absorptive capacity (AC) & .88 & .93 & .67 & \\
Resource availability (RA) & .91 & & \\
\hline
\end{tabular}

Further to this, discriminant validity was evaluated by comparing the square root of the AVE for a given construct with its correlations between other constructs. The discriminant validity is achieved if the square root of AVE exceeds the correlations (Fornell \& Larcker, 1981). As Table 3 illustrates, all constructs had higher values of squared AVE compared with their correlations, thus demonstrating discriminant validity (Nunnally, 1978; Hair, 1998).

Table 3. Validity analysis

\begin{tabular}{lllllllll}
\hline Construct & $\boldsymbol{M}$ & $\boldsymbol{S D}$ & $\mathbf{O P}$ & TT & RA & STA & TA & AC \\
\hline Organizational performance (OP) & 6.10 & 1.02 & $\mathbf{. 7 7}$ & & & & & \\
Technology transfer (TT) & 4.43 & 1.12 & .28 & .77 & & & & \\
Resource availability (RA) & 5.39 & 1.12 & .41 & .16 & $\mathbf{. 8 2}$ & & & \\
Strategic technology alliance (STA) & 2.08 & 1.12 & .71 & .12 & .56 & $\mathbf{n} / \mathbf{a}$ & & \\
Type of alliance (TA) & 5.48 & 1.08 & .55 & .21 & .71 & .65 &. $\mathbf{7 9}$ & \\
Absorptive capacity (AC) & 5.53 & 0.97 & .49 & .14 & .56 & .60 & .61 & $\mathbf{. 8 2}$ \\
\hline
\end{tabular}

Note: The bold numbers in diagonal row are the square root AVE values, $M=$ Mean, $S D=$ Standard deviation, $\mathrm{n} / \mathrm{a}=$ STA is measured using an ordinal scale

\subsection{Structural Model and Hypothesis Testing}

Assuming that the measurement model satisfied the measurement invariance, various reliability, and validity statistical analyses, our results showed a parsimonious model after post-hoc modification with $\chi^{2}(d f=6, N=335)$ $=15.05, p=.02$; Bollen-Stine $p=0.24(\mathrm{SRMR}=0.03$, GFI $=0.96, \mathrm{CFI}=0.99, \mathrm{NFI}=0.98$, TLI $=0.98$ and RMSEA $=0.07$ ) (Bentler \& Bonnet, 1980; Browne \& Cudeck, 1993). Figure 2 shows the parameter estimates and their significance. 


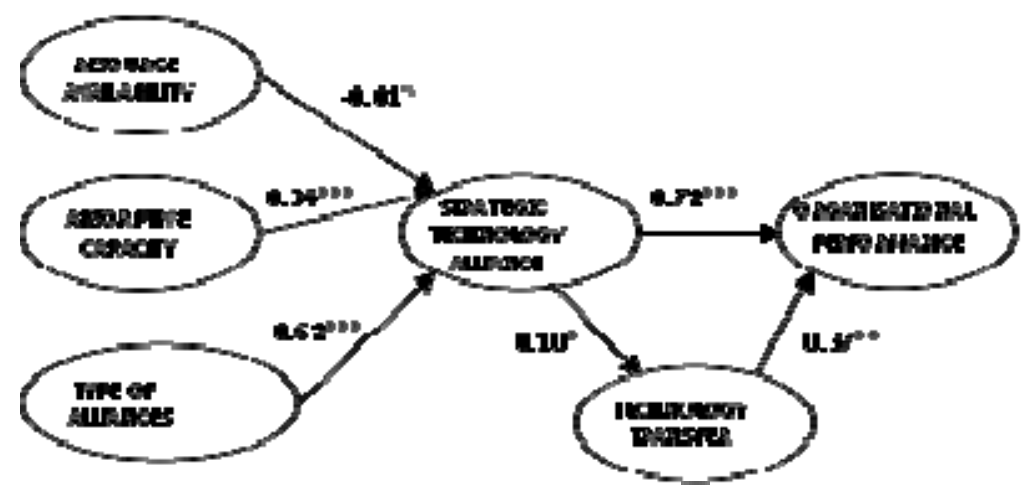

Figure 2. SEM analysis of the research model

Note: ${ }^{* * *} p<.001,{ }^{* *} p<.01, * p<.05$, ns $=$ not significant

Four out of the five hypotheses were supported (see Table 4). Absorptive capacity positively affects STA, therefore supporting Hypothesis 2. The findings in the structural model confirm other studies in that absorptive capacity leads to successful alliances (Cohen \& Levinthal, 1990; Szulanski, 1996; Tidd \& Brocklehurst, 1999). Additionally Hypothesis 3 is also supported, indicating that the type of alliance impacts the STA (Anand \& Khanna, 2000; Dussauge, Garrette, \& Mitchell, 2000; Simonin, 2004), and that that STA also impacts organizational performance (Hypothesis 4). However, there is no support on the hypothesized negative relationship between resource availability and the STA. This result contradicts our hypothesized belief (Hypothesis 1) that these firms will enter into collaborations to procure critical resources (Pisano, 1989; Hamel, 1991), such as assets, technology, technical knowledge, and specific skills.

Table 4. Results of hypothesis testing

\begin{tabular}{llllll}
\hline Predictor variable & Criterion variables & $\boldsymbol{t}$-value & $\boldsymbol{p}$-value & Hypotheses & Results \\
\hline Resource availability & Strategic technology alliance & -.01 & .88 & $H 1$ & Not supported \\
Absorptive capacity & Strategic technology alliance & .34 & $* * *$ & $H 2$ & Supported \\
Type of Alliance & Strategic technology alliance & .62 & $* * *$ & $H 3$ & Supported \\
Strategic technology alliance & Organizational performance & .72 & $* * *$ & $H 4$ & Supported \\
\hline
\end{tabular}

\subsection{Analysis of Mediating Relationship}

Table 5. Results of mediating effects

\begin{tabular}{|c|c|c|c|c|c|c|c|c|c|}
\hline \multirow{2}{*}{ Paths } & \multicolumn{3}{|c|}{ Model 1 Partial mediation } & \multicolumn{3}{|c|}{ Model 2 Full mediation } & \multicolumn{3}{|c|}{ Model 3 No mediation } \\
\hline & $\chi^{2}$ & $d f$ & $\beta$ & $\chi^{2}$ & $d f$ & $\boldsymbol{\beta}$ & $\chi^{2}$ & $d f$ & $\beta$ \\
\hline STA à OP & & & $.71 * * *$ & & & 0 & & & $.72 * * *$ \\
\hline STA à TT & 33.22 & 14 & $.10 * *$ & 263.99 & 15 & $.19 * * *$ & 39.90 & 15 & 0 \\
\hline TT à OP & & & $.36 * * *$ & & & $.76^{* * *}$ & & & $.38^{* * *}$ \\
\hline \multirow{2}{*}{\multicolumn{4}{|c|}{$\begin{array}{l}\Delta \Delta \text { Chi-square } \\
\text { Goodness-of-fit measures }\end{array}$}} & \multicolumn{3}{|c|}{$\Delta \Delta \chi^{2}=230.77$ (1) $p<.001$} & \multicolumn{3}{|c|}{$\Delta \Delta \chi^{2}=6.68(1) p=.01$} \\
\hline & \multicolumn{9}{|c|}{ Goodness-of-fit measures } \\
\hline$p$-value & .00 & & & .00 & & & .00 & & \\
\hline Bollen-Stine $p$ & .09 & & & .00 & & & .03 & & \\
\hline SRMR & .03 & & & .16 & & & .07 & & \\
\hline GFI & .98 & & & .89 & & & .98 & & \\
\hline TLI & .97 & & & .59 & & & .96 & & \\
\hline NFI & .98 & & & .86 & & & .98 & & \\
\hline CFI & .99 & & & .86 & & & .99 & & \\
\hline RMSEA & .06 & & & .22 & & & .07 & & \\
\hline
\end{tabular}


Technology transfer may mediate the effect of STA on organizational performance; hence, this relationship is further examined by conducting nested model comparisons. First, Model 1 (partially mediated model) is tested with the presence of all direct and indirect pathways to organizational performance. Secondly, Model 2 (fully mediated model) is tested with the pathway from STA to organizational performance constrained to zero. Model 2 led to a significant $\chi^{2}$ difference when compared to Model $1\left(\mathrm{D} \chi^{2}=230.77(1) p<.001\right)$ suggesting that the partial mediated model is a better fit to the data. Thirdly, Model 3 tests for no mediation relationship with the pathway from STA to technology transfer constrained to zero. Model 3 also tests for no mediation between STA and organizational performance, and led to a significant $\chi^{2}$ difference when compared with Model $1\left(\mathrm{D} \chi^{2}=6.68\right.$ (1) $p=.01$ ), suggesting that technology transfer only partially mediates STA and organizational performance as in Table 5.

\section{Discussion and Conclusion}

The investigation of alliances has been approached from various theoretical viewpoints. This study contributes to the emerging research on STAs from the perspective of a developing nation through the lenses of the resource-based view and organizational learning. The analyses demonstrate the association of the factors affecting STAs in manufacturing firms with organizational performance and technology transfer. In light of the resource-based view, firms possess idiosyncratic resources that are the source of competitive advantage. While it is important for these firms to analyse gaps in manufacturing skills, capabilities, or technologies (Grant, 1991; Hitt, Ireland, \& Lee, 2000), one way of surmounting this is to enhance their resource base by devoting more efforts in technology collaborations to access such resources externally, and where STAs can enable the synergistic interaction of complementary resources between firms to create superior value. The first hypothesis was not supported in this study, and this interpretation is discordant to the general belief that firms enter into alliances to acquire resources that are lacking within. Our findings suggest that firms need to possess adequate and appropriate resources first before seeking to enhance existing resources or acquiring new technological resources from collaborations. This is in line with Eisenhardt and Schoonhoven's (1996, p. 147) work where they also argue that 'corporations need resources to get resources'. Many Malaysian firms are still possibly in the growth-stage and have few resources to offer their potential partners. To assimilate new technologies and manufacturing processes, these firms need to secure complementary resources that can attract partnerships, the capacity to harness new knowledge, and the ability to exploit technologies in production systems effectively.

Furthermore, absorptive capacity is required for effective collaboration and learning (Mowery, Oxley, \& Silverman, 1996; Lane \& Lubatkin, 1998) because it is largely dependent on the organization's current technological knowledge base (Schoenmakers \& Duysters, 2006) and the ability to reap and exploit additional skills in the alliance. There is a need to assess the relatedness and differences in skills and knowledge between organizations in order to utilize or exploit learning opportunities as a means for successful technology alliance outcomes. The creation, transfer, and absorption of technology and knowledge depend on the learning context and environment. In ensuring successful learning between alliance partners, the new technology needs to be easily understood and compatible with business culture, operational priorities, business objectives, and strategic resources.

Ensuring the right type of alliance is vital to achieving successful collaborations. For example, forming equity alliances will decrease knowledge loss, and at the same time, increase satisfaction and enhance knowledge assimilation. This is related to the risk, commitment, and equity invested in the partnership, where firms may assess the costs and benefits associated with opportunistic behaviour (Madhok \& Tallman, 1998; Norman, 2004). Apart from economic reasons, equity relationships also require high levels of trust and minimize opportunistic behaviours accordingly (Gulati, 1995).

\section{Managerial Implications}

Our findings offer managers some insight and further discernment in their quest for technology development and enhanced manufacturing operations through alliances. Despite the occurrence of STA formation and successful technology transfer, it appears that many Malaysian manufacturing firms will still need to invest in developing their resources and skills to maximize the full potential of newly industrialized manufacturing methods. This investment is imperative for increasing the technical ability of production engineers and technical employees and consequently benefitting manufacturing outcomes. The results of this study indicate that STAs play a significant role on sustained production, profits, sales, and market share; and that STAs should be regarded as an effective mechanism to create competitive advantage for the firms (Awazu, 2006). Although transferring knowledge seems difficult, the formation of alliances will facilitate learning by providing the expectation of a stable, long-term relationship that allows trust and knowledge sharing to develop over time. The role of management is 
to ensure positive learning environments, as well as employee motivation and commitment in the organization. To enable this, various human resource development programs, such as skills development initiatives, profit-sharing schemes, or incentives, can be implemented to ensure that technological knowledge is accumulated continuously into human resources involved in production activities. Organizations will need to establish formalized processes to internalize newly developed innovations and knowledge spill overs.

Additionally, managers should be aware that other benefits that are intangible in nature (e.g., tacit knowledge, intellectual capital, human competencies, Just-in-time systems, quality improvement, and process design, to name a few) are accrued from the alliance apart from the technology transferred that can enhance overall firm performance. The actual technology in itself may be secondary to financial performance or market share; thereby explaining technology transfer as a partial mediator of performance. Furthermore, managers will have to apprehend risks in technology uncertainty and obsolescence, as well as sustained inter-organizational relationships with alliance partners (Stock \& Mohan, 2008). Results of our study further strengthen Awazu's (2006) argument that STAs without technology transfer as an outcome can also improve the organizational performance, such as in licensing agreements and marketing and distribution agreements.

Developing countries play a significant role in the global economy, with a growing number of manufacturing facilities and operations set up by well-known multinational firms from industrialized nations that capitalize on abundant resources and cheaper labour costs. On the other hand, firms from developing countries are also consistently reinforcing manufacturing technology development as a means of industrialization and in staying abreast with more advanced economies. The economic performance of these countries lies in their ability to acquire and adapt new technologies and innovate. It is evident that such countries tend to focus on collaborations with more advanced countries to accelerate their economic growth (Ghosh, 1996). As there are limited empirical studies in Malaysia (See et al., 2007; Rahman, Bennett, \& Sohal, 2009), this study sought to address the gap in the existing literature by exploring the technological perspective of alliances formed by Malaysian manufacturing organizations. Technology development remains a constant issue in Malaysia, as managers strive to create strong high-technology industries that can compete successfully in global markets while moving their national economy in the direction of prosperity.

\section{Limitations and Future Research}

The findings presented in this study must be understood in the context of the following limitations: firstly, it was difficult to identify organizations that had some form of technology alliance before implementing the survey; otherwise, a more effective sampling technique, such as stratified random sampling, would have been adopted. Additionally, the sample from this study was attained from the FMM directory, thereby limiting the population to only those organizations in this database. Although non-response bias was not a concern in this study, it is suggested that subsequent research in Malaysia should include other databases for a more robust population sampling.

Secondly, respondents who participated in the survey were required to consider their best alliance partner in order to evaluate the STA outcomes. Therefore, these analyses and results should be understood as applied to successful STAs that may not necessarily have resulted in technology transfer. Thirdly, since data were collected only from manufacturers in Malaysia, the findings and conclusions cannot be generalized. We believe that future comparative studies on STAs formed by manufacturers from other countries may be beneficial to appreciate further the research framework in this study. Additionally, further studies could focus on specific types of alliances to gain a more comprehensive understanding. Findings that are more interesting could also be gained by conducting comparative studies and replicating the research design with other industries. Despite these limitations, this study offers some illumination to operations management researchers and practitioners by illustrating STAs in manufacturing in the context of a developing nation.

\section{References}

Ahuja, G. (2000a). Collaboration networks, structural holes, and innovation: A longitudinal study. Administrative Science Quarterly, 45, 425-455. http://dx.doi.org/10.2307/2667105

Ahuja, G. (2000b). The duality of collaboration: Inducements and opportunities in the formation of interfirm lingkages. Strategic Management Journal, 21, 317-343. http://dx.doi.org/10.1002/(SICI)1097-0266(200003) 21:3<317::AID-SMJ90>3.0.CO;2-B

Anand, B. N., \& Khanna, T. (2000). Do firms learn to create value? The case of alliances. Strategic Management Journal, 21, 295-315. http://dx.doi.org/10.1002/(SICI)1097-0266(200003)21:3<295::AID-SMJ91>3.0.CO;2$\mathrm{O}$ 
Antoncic, B., Prodan, I., Hisrich, R. D., \& Scarlat, C. (2007). Technological innovativeness and firm performance in Slovenia and Romania. Post-Communist Economies, 19(3), 281-298. http://dx.doi.org/10.1080/146313707 01503299

Arshad, R. (2002). Control and technology transfer in joint venture. Zhejiang University Press, Hangzhou.

Arya, B., \& Lin, Z. J. (2007). Understanding collaboration outcomes from an extended resource-based view perspective: the roles of organizational characteristics, partner attributes, and network structures. Journal of Management, 33(5), 697-723. http://dx.doi.org/10.1177/0149206307305561

Awazu, Y. (2006). Managing technology alliances: The case for knowledge management. International Journal of Information Management, 26, 484-493. http://dx.doi.org/10.1016/j.ijinfomgt.2006.07.005

Bagozzi, R., \& Yi, Y. (1991). Multitrait-multimethod matrices in consumer research. Journal of Consumer Research, 17(1), 426-439. http://dx.doi.org/10.1086/208568

Bakerma, H. G., Shenkar, O., Vermeulen, F., \& Bell, J. H. J. (1997). Working abroad, working with others: How firms learn to operate international joint ventures. Academy of Management Journal, 17, 426-442.

Barney, J. (1991). Firm resources and sustained competitive advantage. Journal of Management, 17(1), 99-120. http://dx.doi.org/10.1177/014920639101700108

Bentler, P. M., \& Bonnet, D. G. (1980). Significance tests and goodness of fit in the analysis of covariance structures. Psychological Bulletin, 88, 588-606. http://dx.doi.org/10.1037/0033-2909.88.3.588

Bhaskaran, S., \& Gligorovska, E. (2009). Influence of national culture on trans-national alliance relationships. Cross Cultural Management-An International Journal, 16(1), 44-61. http://dx.doi.org/10.1108/135276009 10930031

Bierly III, P. E. (2004). Equity alliances, stages of product development, and alliance instability. Journal of Engineering and Technology Management, 21, 191-214. http://dx.doi.org/10.1016/j.jengtecman.2004.05.001

Browne, M. W., \& Cudeck, R. (1993). Alternative ways of assessing model fit. In K. A. Bollen, \& J. S. Long (Eds.), Testing structural equation models (pp. 136-162). Sage, Newbury Park, CA.

Chen, P. H., \& Wang, J. Q. (2009). Technological innovation and technology-intensive manufacturer: A case study of CSR. Hubei People's Press, Wuhan.

Chung, S. A., Singh, H., \& Lee, K. (2000). Complementarity, status similarity and social capital as drivers of alliance formation. Strategic Management Journal, 21, 1-22. http://dx.doi.org/10.1002/(SICI)1097-0266 (200001)21:1<1::AID-SMJ63>3.0.CO;2-P

Cohen, W. M., \& Levinthal, D. A. (1989). Innovation and learning: the two faces of R\&D. The Economic Journal, 99, 569-596. http://dx.doi.org/10.2307/2233763

Cohen, W. M., \& Levinthal, D. A. (1990). Absorptive capacity: A new perspective on learning and innovation. Administrative Science Quarterly, 35, 128-152. http://dx.doi.org/10.2307/2393553

Collins, J. D., \& Hitt, M. A. (2006). Leveraging tacit knowledge in alliances: The importance of using relational capabilities to build and leverage relational capital. Journal of Engineering and Technology Management, 23, 147-167. http://dx.doi.org/10.1016/j.jengtecman.2006.06.007

Colombo, M. G. (1995). Firm size and cooperation: The determinants of cooperative agreements in information technology industries. International Journal of the Economics of Business, 2, 3-29. http://dx.doi.org/10.1080/ 758521094

Colombo, M. G., Grilli, L., \& Piva, E. (2006). In search of complementary assets: The determinants of alliance formation of high-tech start-ups. Research Policy, 35, 1166-1199. http://dx.doi.org/10.1016/j.respol.2006. 09.002

Das, T. K., \& Teng, B. S. (1998). Resource and risk management in the strategic alliance making process. Journal of Management, 24(1), 21-42. http://dx.doi.org/10.1016/S0149-2063(99)80052-X

Department of Statistics Malaysia. (2009). Annual manufacturing industries: Summary findings. Putrajaya.

Di Benedetto, C. A., Calantone, R. J., \& Zhang, C. (2003). International technology transfer: Model and exploratory study in the People's Republic of China. International Marketing Review, 20(4), 446-462. http://dx.doi.org/10.1108/02651330310485171

Dogsdon, M. (1993). Organizational learning: A review of some literature. Organization Studies, 14, $375-395$. http://dx.doi.org/10.1177/017084069301400303

Doz, Y. L., Olk, P., \& Ring, P. S. (2000). Formation processes of R\&D consortia: Which path to take? Where does it lead? Strategic Management Journal, 21(3), 239-266. http://dx.doi.org/10.1002/(SICI)1097-0266(200003) 


\section{1:3<239::AID-SMJ97>3.0.CO;2-K}

Dunne, D. D., Gopalakrishnan, S., \& Scillitoe, J. L. (2009). An empirical study of the impact of firm resources on alliance governance structures. Journal of Engineering and Technology Management, 26, 181-195. http://dx.doi.org/10.1016/j.jengtecman.2009.06.004

Dussauge, P., Garrette, B., \& Mitchell, W. (2000). Learning from competing partners: Outcomes and durations of scale and link alliances in Europe, North America and Asia. Strategic Management Journal, 21, 99-126. http://dx.doi.org/10.1002/(SICI)1097-0266(200002)21:2<99::AID-SMJ80>3.0.CO;2-G

Economic Planning Unit. (2006). Ninth Malaysia Plan 2006-2010. Putrajaya.

Eisenhardt, K. M., \& Schoonhoven, C. B. (1996). Resource-based view of strategic alliance formation: Strategic and social effects in entrepreneurial firms. Organization Science, 7(2), 136-150. http://dx.doi.org/10.1287 /orsc.7.2.136

Erensal, Y. C., \& Albayrak, Y. E. (2008). Transferring appropriate manufacturing technologies for developing countries. Journal of Manufacturing Technology Management, 19(2), 158-171. http://dx.doi.org/10.1108/174 10380810847891

Evans, N. (2001). Collaborative strategy: An analysis of the changing world of international airline alliances. Tourism Management, 22(3), 229-243. http://dx.doi.org/10.1016/S0261-5177(01)00024-3

Fang, E., \& Zou, S. M. (2010). The effects of absorptive and joint learning on the instability of international joint ventures in emerging economies. Journal of International Business Studies, 41(5), 906-924. http://dx.doi.org/ 10.1057/jibs.2009.100

Fornell, C., \& Larcker, D. F. (1981). Evaluating structural equation models with unobserved variables and measurement error. Journal of Marketing Research, 18(1), 39-50. http://dx.doi.org/10.2307/3151312

Garver, M. S., \& Mentzer, J. T. (1999). Logistics research methods: Employing structural equation modeling to test for construct validity. Journal of Business Logistics, 20(1), 33-57.

Geringer, J., \& Hebert, L. (1991). Measuring performance of international joint ventures. Journal of International Business Studies, 22(2), 249-263. http://dx.doi.org/10.1057/palgrave.jibs.8490302

Ghani, A. B. A., \& Subhan, M. (2005). The coevolution of trust, control and partner selection in Malaysia-Indonesia strategic alliances. The Global Studies Journal, 2(2), 89-103.

Ghosh, S. R. (1996). Reverse lingkages: The growing importance of developing countries. Retrieved August 30, 2010, from http://www.allbusiness.com/government/565709-1.html

Goerzen, A. (2007). Alliance Networks and firm performance: The impact of repeated partnerships. Strategic Management Journal, 28, 487-509. http://dx.doi.org/10.1002/smj.588

González-Alvarez, N., \&d Nieto-Antolín, M. (2005). Protection and internal transfer of technological competencies. Industrial Management \& Data Systems, 105(7), 841-856. http://dx.doi.org/10.1108/02635570 510616076

Grant, R. M. (1991). The resource-based theory of competitive advantage: Implications for strategy formulation. California Management Review, 33(3), 114-135. http://dx.doi.org/10.2307/41166664

Green, S. G., Welsh, M. A., \& Dehler, G. E. (1996). Transferring technology into R\&D: a comparison of acquired and in-house product development projects. Journal of Engineering and Technology Management, 13, 125-144. http://dx.doi.org/10.1016/S0923-4748(96)01000-4

Guan, J. C., Mok, C. K., Yam, R. C. M., Chin, K. S., \& Pun, K. F. (2006). Technology transfer and innovation performance: Evidence from Chinese firms. Technological Forecasting and Social Change, 73(6), 666-678. http://dx.doi.org/10.1016/j.techfore.2005.05.009

Gulati, R. (1995). Does familiarity breed trust? The implications of repeated ties for contractual choice in alliances. Academy of Management Journal, 38(1), 85-112. http://dx.doi.org/10.2307/256729

Gulati, R., Nohria, N., \& Zaheer, A. (2000). Strategic networks. Strategic Management Journal, 21, 199-201. http://dx.doi.org/10.1002/(SICI)1097-0266(200003)21:3<199::AID-SMJ98>3.0.CO;2-0

Hagedoorn, J., \& Schakenraad, J. (1994). The effect of strategic technology alliances on company performance. Strategic Management Journal, 15(4), 291-309. http://dx.doi.org/10.1002/smj.4250150404

Hagedoorn, J., \& Sedaitis, J. B. (1998). Partnership in transition economies: International strategic technology alliances in Russia. Research Policy, 27, 177-185. http://dx.doi.org/10.1016/S0048-7333(98)00035-3

Hagedoorn, J., Carayannis, E., \& Alexander, J. (2001). Strange bedfellows in the personal computer industry: Technology alliances between IBM and Apple. Research Policy, 30, 837-849. http://dx.doi.org/10.1016/S00 


\section{8-7333(00)00125-6}

Hair, J. F. (1998). Multivariate data analysis. Prentice Hall, Upper Saddle River, NJ.

Hamel, G. (1991). Competition for competence and interpreter learning within international strategic alliances. Strategic Management Journal, 12, 83-103. http://dx.doi.org/10.1002/smj.4250120908

Hastings, D. F. (1999). Lincoln Electric's harsh lessons from international expansion. Harvard Business Review, 77(3), 162-178.

Henderson, R., \& Cockburn, I. (1996). Scale, scope and spillovers: The determinants of research productivity in drug discovery. The RAND Journal of Economics, 27(1), 32-59. http://dx.doi.org/10.2307/2555791

Hitt, M. A. (1998). Twenty-first century organizations: Business firms, business schools, and the academy. Academy of Management Review, 23, 218-224. http://dx.doi.org/10.5465/amr.1998.533223

Hitt, M. A., Dacin, M. T., Levitas, E., Arregle, J. L., \& Borza, A. (2000). Partner selection in emerging and developed market context: Resource-based and organizational learning perspectives. Academy of Management Journal, 43(3), 449-467. http://dx.doi.org/10.2307/1556404

Hitt, M. A., Ireland, R. D., \& Lee, H. U. (2000). Technological learning, knowledge management, firm growth and performance: An introductory essay. Journal of Engineering and Technology Management, 17, 231-246. http://dx.doi.org/10.1016/S0923-4748(00)00024-2

Hoffman, K., \& Girvan, N. (1990). Managing international technology transfer: A strategic approach for developing countries. IDRC, Ottawa, ON.

Ireland, R. D., \& Hitt, M. A. (1999). Achieving and maintaining strategic competitiveness in the 21st century: The role of strategic leadership. Academy of Management Executive, 13(1), 43-57.

Jamali, D. (2004). Success and failure mechanisms of public private partnerships (PPPs) in developing countries: Insights from the Lebanese context. International Journal of Public Sector Management, 17(5), 414-430. http://dx.doi.org/10.1108/09513550410546598

Jegathesan, J., Gunasekaran, A., \& Muthaly, S. (1997). Technology development and transfer: Experience from Malaysia. International Journal of Technology Management, 13(2), 196-214. http://dx.doi.org/10.1504/IJTM. 1997.001655

Jones, G. K., Lanctot, A., \& Teegen, H. J. (2000). Determinants and performance impacts of external technology acquisition. Journal of Business Venturing, 16, 255-283. http://dx.doi.org/10.1016/S0883-9026(99)00048-8

Ju, T. L., Chen, S. H., Li, C. Y., \& Lee, T. S. (2005). A strategic contingency model for technology alliance. Industrial Management \& Data Systems, 105(5), 623-644. http://dx.doi.org/10.1108/02635570510599995

Judge, W. Q., \& Dooley, R. (2006). Strategic alliance outcomes: A transaction-cost economics perspective. British Journal of Management, 17, 23-37. http://dx.doi.org/10.1111/j.1467-8551.2005.00441.x

Kim, Y. (2009). Choosing between international technology licensing partners: An empirical analysis of U.S biotechnology firms. Journal of Engineering and Technology Management, 26, 57-72. http://dx.doi.org/10. 1016/j.jengtecman.2009.03.003

Kotabe, M., Martin, X., \& Domoto, H. (2003). Gaining from vertical partnerships: Knowledge transfer, relationship duration, and supplier performance improvement in the US and Japanese automotive industries. Strategic Management Journal, 24(4), 293-316. http://dx.doi.org/10.1002/smj.297

Kumar, V., Kumar, U., \& Persaud, A. (1999). Building technological capability through importing technology: The case of Indonesian manufacturing industry. Journal of Technology Transfer, 24, 81-96. http://dx.doi.org /10.1023/A:1007728921126

Lane, P. J., \& Lubatkin, M. (1998). Relative absorptive capacity and interorganizational learning. Strategic Management Journal, 19, 461-477. http://dx.doi.org/10.1002/(SICI)1097-0266(199805)19:5<461::AID-SM J953>3.0.CO;2-L

Lee, C. W. (2007). Strategic alliances influence on small medium firm performance. Journal of Business Research, 60, 731-741. http://dx.doi.org/10.1016/j.jbusres.2007.02.018

Lee, H. H., \& Tan, H. B. (2006). Technology transfer, FDI and Growth in the ASEAN Region. Journal of the Asia Pacific Economy, 11(4), 394-410. http://dx.doi.org/10.1080/13547860600923593

Lei, D. (1993). Offensive and defensive uses of alliances. Long Range Planning, 26(4), 32-41. http://dx.doi.org/10. 1016/0024-6301(93)90055-K

Lyles, M. A., Sulaiman, M., Barde, J. Q., \& Kechik, A. R. A. (1999). Factors affecting international joint venture performance: A study of Malaysian joint ventures. Journal of Asian Business, 15(2), 1-19. 
Lynch, R. P. (1989). The practical guide ventures and alliances. Wiley, New York.

Madhok, A., \& Tallman, S. B. (1998). Resources, transactions, and rent: Managing value through interfirm collaborative relationships. Organization Science, 9(3), 326-339. http://dx.doi.org/10.1287/orsc.9.3.326

Malaysian Industrial Development Authority. (2008). The Malaysian Industrial Development Authority. Kuala Lumpur. Retrieved April 6, 2008, from http://www.mida.gov.my

McEvily, S. K., Eisenhardt, K. M., \& Prescott, J. E. (2004). The global acquisition, leverage, and protection of technological competencies. Strategic Management Journal, 25, 294-311. http://dx.doi.org/10.1002/smj.425

McGee, J. E., Dowling, M. J., \& Megginson, W. L. (1995). Cooperative strategy and new venture performance: The role of business strategy and management experience. Strategic Management Journal, 16, 565-580. http://dx.doi.org/10.1002/smj.4250160706

Ministry of International Trade and Industry. (2010). UNCTAD Reports Impressive FDI Growth In Malaysia In 2010 Kuala Lumpur. Retrieved November 28, 2011, from http://www.miti.gov.my/cms/content.jsp?id=com. tms.cms.article.Article_bbf10ab7-c0a8156f-39323932-a4c03420

Ministry of Science Technology and Innovation. (2010). Ministry of Science, Technology and Innovation, Kuala Lumpur. Retrieved October 8, 2010, from http://www.mosti.gov.my/mosti/

Mockler, R. J. (2001). Making decisions on enterprise-wide strategic alignment in multinational alliances. Management Decision, 39(2), 90-98. http://dx.doi.org/10.1108/EUM0000000005414

Mohamed, M. Z. (1995). Innovation implementations in Malaysian firms: Process, problems, critical success factors and working climate. Technovation, 15(6), 375-385. http://dx.doi.org/10.1016/0166-4972(95)96598-N

Montoya, P. V., Zarate, R. S., \&d Martin, L. A. G. (2007). Does the technological sourcing decision matter? Evidence from Spanish panel data. R\&D Management, 37, 161-172. http://dx.doi.org/10.1111/j.1467-9310. 2007.00465.x

Mowery, D. C., \& Rosenberg, N. (1989). Technology and the pursuit of economic growth. Cambridge University Press, Cambridge. http://dx.doi.org/10.1017/cbo9780511664441

Mowery, D. C., Oxley, J. E., \& Silverman, B. S. (1996). Strategic alliances and interfirm knowledge transfer. Strategic Management Journal, 17, 77-91. http://dx.doi.org/10.1002/smj.4250171108

Nagarajan, A., \&, Mitchell, W. (1998). Evolutionary diffusion: Internal and external methods used to acquire encompassing, complementary, and incremental technological changes in the lithotripsy industry. Strategic Management Journal, 19, 1063-1077. http://dx.doi.org/10.1002/(SICI)1097-0266(1998110)19:11<1063::AID $-\mathrm{SMJ} 993>3.0 . \mathrm{CO} ; 2-\mathrm{W}$

Nielsen, B. B. (2007). Determining international strategic alliance performance: A multidimensional approach. International Business Review, 16, 337-361. http://dx.doi.org/10.1016/j.ibusrev.2007.02.004

Norman, P. M. (2004). Knowledge acquisition, knowledge loss, and satisfaction in high technology alliances. Journal of Business Research, 57, 610-619. http://dx.doi.org/10.1016/S0148-2963(02)00395-8

Nunnally, J. C. (1978). Psychometric theory. McGraw-Hill, New York.

Parkhe, A. (1993). "Messy" research, methodological predispositions, and theory development in international joint ventures. Academy of Management Review, 18(2), 227-268.

Pateli, A. G. (2009). Decision making on governance of strategic technology alliances. Management Decision, 47(2), 246-270. http://dx.doi.org/10.1108/00251740910938902

Peek, J., Rosengren, E. S., \& Kasirye, F. (1999). The poor performance of foreign bank subsidiaries: Were the problems acquired or created? Journal of Banking and Finance, 23(2-4), 579-604. http://dx.doi.org/10.1016 /S 0378-4266(98)00082-X

Pellicelli, A. C. (2003). Strategic alliances. Faculty of Economics, University of Piemonte Orientale "A. Avogadro" Novara, Italy.

Perez-Nordtvedt, L., Babakus, E., \& Kedia, B. L. (2010). Learning from international business affiliates: Developing resource-based learning capacity through networks and knowledge acquisition. Journal of International Management, 16(3), 262-274. http://dx.doi.org/10.1016/j.intman.2010.06.005

Pisano, G. (1989). Using equity participation to support exchange: Evidence from the biotechnology industry. Journal of Law, Economics, and Organization, 5(1), 109-126.

Poon, J. P. H. (2005). Innovation strategies of Asian firms in the United States. Journal of Engineering and Technology Management, 22, 255-273. http://dx.doi.org/10.1016/j.jengtecman.2005.09.001

Rahman, A. A., Bennett, D., \& Sohal, A. (2009). Transaction attributes and buyer-supplier relationships in AMT 
acquisition and implementation: The case of Malaysia. International Journal of Production Research, 47(9), 2257-2278. http://dx.doi.org/10.1080/00207540802471298

Rashid, L., Yahya, S., Shamee, S. A., Jabar, J., Sedek, M., \& Halim, S. (2014). Eco Product Innovation in Search of Meaning: Incremental and Radical Practice for Sustainability Development. Asian Social Science, 10(13), 78. http://dx.doi.org/10.5539/ass.v10n13p78

Rashid, N., Jabar, J., Yahya, S., \& Shami, S. (2014). Dynamic Eco Innovation Practices: A Systematic Review of State of the Art and Future Direction for Eco Innovation Study. Asian Social Science, 11(1), 8. http://dx.doi. org/10.5539/ass.v11n1p8

Rothaermel, F. T., \& Deeds, D. L. (2006). Alliance type, alliance experience and alliance management capability in high-technology ventures. Journal of Business Venturing, 21, 429-460. http://dx.doi.org/10.1016/j.jbusvent. 2005.02.006

Sadowski, B., \& Duysters, G. (2008). Strategic technology alliance termination: An empirical investigation, Journal of Engineering and Technology Management, 25, 305-320. http://dx.doi.org/10.1016/j.jengtecman. 2008.10.002

Santoro, M. D., \& Chakrabarti, A. K. (2002). Firm size and technology centrality in industry-university interactions. Research Policy, 31, 1163-1180. http://dx.doi.org/10.1016/S0048-7333(01)00190-1

Schoenmakers, W., \& Duysters, G. (2006). Learning in strategic technology alliances. Technology Analysis \& Strategic Management, 18(2), 245-264. http://dx.doi.org/10.1080/09537320600624162

Schweizer, L. (2005). Knowledge transfer and R\&D in pharmaceutical companies: A case study. Journal of Engineering and Technology Management, 22, 315-331. http://dx.doi.org/10.1016/j.jengtecman.2005.09.004

See, A., Geok, O. S., Nair, C., \& Lai, J. (2007). Bilateral collaborative partnership-Joint industry/university perspective. International Journal of Engineering Education, 23(5), 973-980.

Shenkar, O., \& Li, J. (1999). Knowledge search in international cooperative ventures. Organization Science, 10, 134-143. http://dx.doi.org/10.1287/orsc.10.2.134

Simonin, B. L. (2004). An empirical investigation of the process of knowledge transfer in international strategic alliances. Journal of International Business Studies, 35, 407-427. http://dx.doi.org/10.1057/palgrave.jibs. 8400091

Soh, P. H., \& Roberts, E. B. (2005). Technology alliances and networks: An external link to research capability. IEEE Transactions on Engineering Management, 52(4), 419-428. http://dx.doi.org/10.1109/TEM.2005. 850727

Solo, R. A. (1972). Inducing technological change for economic growth and development. Michigan State University Press, East Lansing, MI.

Spivey, W. A., Munson, J. M., Nelson, M. A., \& Dietrich, G. B. (1997). Coordinating the technology transfer and transition of Information Technology: A phenomenological perspective. IEEE Transactions on Engineering Management, 44(4), 359-366. http://dx.doi.org/10.1109/17.649866

Stock, G. N., \& Mohan, V. T. (2008). The joint influence of technology uncertainty and interorganisational interaction on external technology integration success. Journal of Operations Management, 26, 65-80. http://dx.doi.org/10.1016/j.jom.2007.04.003

Stuart, T. E. (2000). Interorganizational alliances and the performance of firms: A study of growth and innovation rates in a high-technology industry. Strategic Management Journal, 21, 791-811. http://dx.doi.org/10.1002/ 1097-0266(200008)21:8<791::AID-SMJ121>3.0.CO;2-K

Sulaiman, M., Kechik, A. R. A., \& Wafa, S. A. (1999). Performance and problems of international joint-ventures in Malaysia. Malaysian Management Review December, 56-64.

Szulanski, G. (1996). Exploring internal stickiness: Impediments to the transfer of best practice within a firm. Strategic Management Journal, 17, 27-43. http://dx.doi.org/10.1002/smj.4250171105

Tidd, J., \& Brocklehurst, M. (1999). Routes to technological learning and development: An assessment of Malaysia's innovation policy and performance. Technological Forecasting and Social Change, 62, 239-257. http://dx.doi.org/10.1016/S0040-1625(99)00047-5

Tsai, K. H. (2009). Collaborative networks and product innovation performance: Toward a contingency perspective. Research Policy, 38(5), 765-778. http://dx.doi.org/10.1016/j.respol.2008.12.012

Tsai, K. H., \& Wang, J. C. (2008). External technology acquisition and firm performance: A longitudinal study. Journal of Business Venturing, 23(1), 91-112. http://dx.doi.org/10.1016/j.jbusvent.2005.07.002 
Tsai, K. H., \& Wang, J. C. (2009). External technology sourcing and innovation performance in LMT sectors: An analysis based on the Taiwanese Technological Innovation Survey. Research Policy, 38, 518-526. http://dx. doi.org/10.1016/j.respol.2008.10.007

Tsang, E. W. K. (2002). Acquiring knowledge by foreign partners from international joint ventures in a transition economy: Learning-by-doing and learning by myopia. Strategic Management Journal, 23(9), 835-854. http://dx.doi.org/10.1002/smj.251

Un, C. A., Cuervo-Cazurra, A., \& Asakawa, K. (2010). R\&D collaborations and product innovation. Journal of Product Innovation Management, 27(5), 673-689. http://dx.doi.org/10.1111/j.1540-5885.2010.00744.x

Uzzi, B. (1997). Social structure and competition in international networks: The paradox of embeddedness. Administrative Science Quarterly, 42(1), 1150-1174. http://dx.doi.org/10.2307/2393808

Vanhaverbeke, W., Duysters, G., \& Noorderhaven, N. (2002). External technology sourcing through alliances or acquisitions: An analysis of the application-specific integrated circuits industry. Organization Science, 13, 714-733. http://dx.doi.org/10.1287/orsc.13.6.714.496

Vilkamo, T., \& Keil, T. (2003). Strategic technology partnering in high-velocity environments - lessons from a case study. Technovation, 23, 193-204. http://dx.doi.org/10.1016/S0166-4972(01)00108-0

Wahab, S. A., Abdullah, H., \& Rose, R. C. (2009). A framework on the effects on inter-firm technology transfer in international joint venture. The Journal of International Social Research, 2(9), 423-443.

Walter, J. (2000). Technological adaptation and learning by cooperation: A case study of a successful onshore technology transfer in Tierra del Fuego. Journal of Technology Transfer, 25(1), 3-22. http://dx.doi.org/10. 1023/A:1007878819270

Ybarra, C. E., \& Turk, T. A. (2009). The evolution of trust in information technology alliances. Journal of High Technology Management Research, 20(1), 62-74. http://dx.doi.org/10.1016/j.hitech.2009.02.003

Zahra, S. A., \& George, G. (2002). Absorptive capacity: A review, reconceptualization, and extension. Academy of Management Review, 27(2), 185-203.

Zhan, W., Chen, R., Erramilli, M., \& Nguyen, D. (2009). Acquisition of organizational capabilities and competitive advantage of IJVs in transition economies: The case of Vietnam. Asia Pacific Journal of Management, 26(2), 285-308. http://dx.doi.org/10.1007/s10490-008-9108-1

\section{Appendix A}

\begin{tabular}{|c|c|c|c|c|c|c|}
\hline \multicolumn{2}{|c|}{ Factors and items } & SFL & $t$-value & SMC & $\begin{array}{l}\text { Composite } \\
\text { reliability }\end{array}$ & AVE \\
\hline \multicolumn{7}{|c|}{ Resource availability $(\mathrm{a}=.91)$} \\
\hline r1 & Our organization has a considerable amount of patents. & .79 & a & .63 & .93 & .67 \\
\hline $\mathrm{r} 2$ & Our organization has a stable cash flow condition. & .84 & 13.38 & .71 & & \\
\hline r3 & $\begin{array}{l}\text { Our organization is actively involved in } \\
\text { commercialization. }\end{array}$ & .66 & 9.90 & .44 & & \\
\hline r4 & $\begin{array}{l}\text { Our organization is highly competent in terms of } \\
\text { manufacturing ability. }\end{array}$ & .79 & 12.40 & .63 & & \\
\hline r5 & $\begin{array}{l}\text { Our organization has a significant number of alliances } \\
\text { formed. }\end{array}$ & .74 & 11.26 & .54 & & \\
\hline r6 & $\begin{array}{l}\text { Our organization is managed by highly experienced } \\
\text { managers. }\end{array}$ & .83 & 13.18 & .69 & & \\
\hline r7 & $\begin{array}{l}\text { Our organization currently possesses the latest } \\
\text { manufacturing technologies. }\end{array}$ & .85 & 13.64 & .73 & & \\
\hline \multicolumn{7}{|c|}{ Absorptive capacity $(a=.88)$} \\
\hline oa1 & $\begin{array}{l}\text { Our organization is highly experienced in terms of } \\
\text { forming alliances. }\end{array}$ & .74 & a & .55 & .91 & .62 \\
\hline oa2 & $\begin{array}{l}\text { Our organization employs numerous experts in a } \\
\text { particular field. }\end{array}$ & .89 & 12.83 & .79 & & \\
\hline oa3 & $\begin{array}{l}\text { Our organization has spent considerable amount of } \\
\text { money to enhance the capacity of our employees. }\end{array}$ & .85 & 12.16 & .72 & & \\
\hline oa4 & Our organization has a specific area of expertise. & .84 & 12.09 & .71 & & \\
\hline oa5 & Our organization has a diverse background of & .75 & 10.72 & .57 & & \\
\hline
\end{tabular}




\begin{tabular}{|c|c|c|c|c|c|c|}
\hline \multicolumn{2}{|c|}{ Factors and items } & \multirow[t]{2}{*}{ SFL } & \multirow[t]{2}{*}{$t$-value } & \multirow[t]{2}{*}{ SMC } & \multirow[t]{2}{*}{$\begin{array}{l}\text { Composite } \\
\text { reliability }\end{array}$} & \multirow[t]{2}{*}{ AVE } \\
\hline & employees. & & & & & \\
\hline oa6 & $\begin{array}{l}\text { Our organization has spent considerable amount of } \\
\text { money in research and development activities. }\end{array}$ & .50 & 6.81 & .24 & & \\
\hline \multicolumn{7}{|c|}{ Type of alliance $(a=.87)$} \\
\hline on 2 & $\begin{array}{l}\text { Our organization believes that equity alliances will lead } \\
\text { to strong learning outcomes. }\end{array}$ & .82 & a & .67 & .86 & .62 \\
\hline on3 & $\begin{array}{l}\text { Our organization believes that joint venture alliances will } \\
\text { lead to strong learning outcomes. }\end{array}$ & .82 & 13.50 & .68 & & \\
\hline on 4 & $\begin{array}{l}\text { Our organization believes that it is important to choose } \\
\text { the right type of alliances for effective learning } \\
\text { outcomes. }\end{array}$ & .80 & 12.97 & .64 & & \\
\hline on5 & $\begin{array}{l}\text { Our organization believes that an alliance is a platform } \\
\text { for learning and knowledge acquisition. }\end{array}$ & .69 & 10.66 & .48 & & \\
\hline \multicolumn{7}{|c|}{ Organizational performance $(a=.82)$} \\
\hline Cap1 & Our organization has increased its market share. & .74 & a & .55 & .75 & .60 \\
\hline Cap2 & Our organization has increased its profit. & .83 & 10.98 & .68 & & \\
\hline Cap3 & Our organization has increased its sales level. & .74 & 9.90 & .55 & & \\
\hline Cap4 & $\begin{array}{l}\text { Our organization has increased its manufacturing } \\
\text { capabilities. }\end{array}$ & .77 & 10.30 & .59 & & \\
\hline \multicolumn{7}{|c|}{ Strategic technology alliance $(a=.86)$} \\
\hline STA1 & $\begin{array}{l}\text { Please estimate the number of joint ventures formed by } \\
\text { your organization in the past three years. }\end{array}$ & $\mathrm{n} / \mathrm{a}$ & $\mathrm{n} / \mathrm{a}$ & $\mathrm{n} / \mathrm{a}$ & .85 & .67 \\
\hline STA2 & $\begin{array}{l}\text { Please estimate the number of equity alliances formed by } \\
\text { your organization in the past three years, }\end{array}$ & $\mathrm{n} / \mathrm{a}$ & $\mathrm{n} / \mathrm{a}$ & $\mathrm{n} / \mathrm{a}$ & & \\
\hline STA3 & $\begin{array}{l}\text { Please estimate the number of non-equity alliances } \\
\text { formed by your organization in the past three years. }\end{array}$ & $\mathrm{n} / \mathrm{a}$ & $\mathrm{n} / \mathrm{a}$ & $\mathrm{n} / \mathrm{a}$ & & \\
\hline \multicolumn{7}{|c|}{ Technology transfer $(a=.85)$} \\
\hline TT1 & $\begin{array}{l}\text { Our organization has derived some form of benefit from } \\
\text { the transfer of technology from our partners. }\end{array}$ & .77 & $\mathrm{a}$ & .60 & .74 & .60 \\
\hline TT2 & $\begin{array}{l}\text { Our organization has been able to develop new } \\
\text { technology or processes as a result. }\end{array}$ & .87 & 12.85 & .76 & & \\
\hline TT3 & $\begin{array}{l}\text { Our organization has increased our R\&D level as a } \\
\text { result. }\end{array}$ & .84 & 12.37 & .70 & & \\
\hline
\end{tabular}

Note: $N=335$; a =loadings are fixed to unity to scale the latent variable; $\mathrm{n} / \mathrm{a}=$ items for this construct utilizes an ordinal scale and was parceled

\section{Copyrights}

Copyright for this article is retained by the author(s), with first publication rights granted to the journal.

This is an open-access article distributed under the terms and conditions of the Creative Commons Attribution license (http://creativecommons.org/licenses/by/3.0/). 